\title{
同位体比から見た松代群発地震地域の深部流体の起源
}

\author{
防災科学技術研究所* 吉 田 則 夫 \\ 信州大学工学系研究科** 奥 澤 保 \\ 信州大学理学部物質㡒環学科*** 塚 原 弘 昭
}

\section{Origin of Deep Matsushiro Earthquake Swarm Fluid Inferred from Isotope Ratios}

\author{
Norio YoshIDA \\ National Research Institute for Earth Science and Disaster Prevention, Tennodai \\ 3-1, Tsukuba, Ibaraki 305-0006, Japan \\ Tamotsu OKusawa \\ Graduate School of Science and Technology. Shinshu University, Asahi \\ 3-1-1, Matsumoto. Nagano 390-8621, Japan \\ Hiroaki TsUKAHARA \\ Department of Environmental Sciences, Faculty of Science, Shinshu University, \\ Asahi 3-1-1, Matsumoto, Nagano 390-8621, Japan
}

(Received October 3, 2001; Accepted August 6, 2002)

\begin{abstract}
In the final stages of the Matsushiro earthquake swarm (August 1965-October 1967), a large volume of ground water was generated that continues to flow as of this writing. We studied the spring water origin by measuring oxygen/hydrogen isotope ratios and concentrations of $\mathrm{Na}^{+}$and $\mathrm{Cl}$, the main dissolved ions. We took water samples from June 1999 to October 2000 . Data plots for $\delta{ }^{18} \mathrm{O}$ vs. $\delta \mathrm{D}$ are distributed along a well determined linear regression line having an endpoint, i. e., river water, at the ordinary value of rainwater. The regression line can be extrapolated toward estimated $\delta^{18} \mathrm{O}$ and $\delta \mathrm{D}$ of "andesitic magmatic water" originating from magma in subduction zones. This implies that the Matsushiro groundwater can be regarded simply as a mixture of 2 fluids, i.e., surface water and andesitic magmatic water. We obtained the carbon isotope ratio of $\mathrm{CO}_{2}$, the main component of free gas in spring water. $\delta^{13} \mathrm{C}$ ranges from $-7.1 \%$ to $-3.1 \%$, suggesting that the source of $\mathrm{CO}_{2}$ is also magmatic. The ratio ${ }^{3} \mathrm{He} /{ }^{4} \mathrm{He}$ shows that $\mathrm{He}$ in the free gas is from the mantle or magma. These 3 pieces of evidence $-(1) \delta{ }^{18} \mathrm{O}$ and $\delta \mathrm{D}$ values, (2) $\delta{ }^{13} \mathrm{C}$ of $\mathrm{CO}_{2}$, and $(3){ }^{3} \mathrm{He} /{ }^{4} \mathrm{He}-$ suggest that the origin of Matsushiro water is magmatic. Considering the presence of an electric conductive layer and seismic reflective layers $15 \mathrm{~km}$ beneath the Matsushiro area, we presume that this andesitic magmatic water accumulates as a thin layer at this depth. An impermeable sheet presumably lying just above the water layer was formed by precipitates from magmatic water.

We present the following model of the relation between groundwater and earthquakes: When the impermeable sheet broke and high-pressure water with $\mathrm{CO}_{2}$ rose into the upper crust, the crust was weakened, causing the Matsushiro earthquake.
\end{abstract}

Key words: groundwater, Matsushiro earthquake swarm, oxygen/hydrogen isotope ratios, andesitic magmatic water, magmatic gas.

* テ305-0006 つくば市天王台 3-1

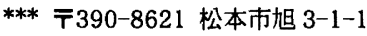

** ₹390-8621 松本市旭 3-1-1 
§1.はじめに

深部流体 (深部地下水) の動きが地震の発生に大きな 影㹕を与えているということは良く知られている[例え ば Healy et al. (1968)]. 最近では1995 年 1 月に発生 し、阪神・淡路地区に大災害をもたらした兵庫県南部地 震である [Tsunogai and Wakita (1995)]. 1965 年 8 月に発生し, 1967 年 10 月にほぼ終息した松代群発地震 は地票と密接な関係のある深部地下水が多量に湧出した ことで知られている [野口・他(1969)]. 松代群発地磭 は $\mathrm{CO}_{2}$ を主成分とし、 $\mathrm{CH}_{4}$ を数十〜数干 $\mathrm{ppm}$ 含む遊離 ガスを付随した高塩分渡度の地下水の涌出を特街とする [細野 (1968), 野口・他 (1969), 鶴見 (1979), Yoshioka et al. (1970)] 地下水が引き起こした典型的な地震の一 つである [大竹 (1976)]. 断層運動による地割れは皆神 山（みなかみやま）北東部に現れ，この地割れ地帯から 多量の地下水が湧出した [Tsuneishi and Nakamura (1970)]. 地下水湧出の終了後まもなく地縟活動が低下し たことから, 松代群発地榐と地下水との密接な関連を述 ベている研究が数多くみられる [Kisslinger (1975), 中 村 (1971), Nur (1974), Stuart and Johnston (1975)]. また、飯島 (1969)によれば地下水の総湧出量は $10^{7} \mathrm{~m}^{3}$ と莫大な量であった，中村 (1971) は松代群発地震の発 生要因として地下深部から水が急上昇してきたとする水 噴火説を, 恒石・高橋 (1975) は深部地下水が急上昇し た原動力として，炭酸ガスの発泡を考える炭酸ガス・水 噴火説を提唱した。群発地震の発生期間中, 多量の湧出 が続いた地下水の化学的特徵は, $\mathrm{Na}^{1}, \mathrm{Cl}^{-}, \mathrm{Ca}^{2}{ }^{\prime}, \mathrm{CO}_{2}$ の含有量が異常に高いことであった：このことからこの 地下水の起源としては化石海水あるいは，マグマから発 生した塩素ガスが地下深部の石灰岩と反応して $\mathrm{CO}_{2}$ と $\mathrm{CaCl}_{2}$ を形成し，これらを溶解した地下水が上昇したと する考え方等があるが、まだ結論は出ていない，Wakita et al. (1978) は, 群発地票終息約 10 年後に潜在断層上 から採取した土墥ガス中のヘリウム同位体比の值がマン トルの值に近いことから,この地下水の起源を上部マン トルから上昇した安山岩質ダイアピルマグマの泠却によ る水の放出だと考えた. 大竹 (1976) は化石海水と岩石 からの脱水反応により放出された水との混合とし、笹井 (1994)は下部地款に電気伝導度の高い領域が存在する ことから、この良導層を自由水と考え，この下部地殼の 高塩分濃度の水か群発地震に関与しているものと考え た. 松葉谷・他 (1980) は涌水の起源を化石海水と地表 水との混合とした． $\mathrm{CO}_{2}$ が土埕中に高謴度含まれること に着目した清水・他(1998)は, 松代群発地票地域にほ ほ北西一南東方向に走る地票断層の南北伸縮と土壤 $\mathrm{CO}_{2}$ 濃度变化とがよい相関を示すことを見いだした，塚
原・他 (1998) は群発地䢅が発生してから 4 年後に掘削 された調查用ボーリング孔から自噴した地下水を深部流 体に近い組成を持つと考え，その同位体比を $\delta^{18} \mathrm{O}=$ $+2 \%, \delta \mathrm{D}=-30 \%$ と見皘もり，深部流体を化石海水之 する積極的根拠は薄いとした．また湧水の溶存イオン湍 度の長期経時变化を観測した奥澤・塚原 (2001) は松代 湧水中の溶存イオン濃度の变化機構を深部地下水之浅届 水の 2 液混合で定性的に説明した。 また奥㳯・塚原 (2002) は松代町の極く近傍で発生した地票の際, 湧水中 の溶存イオン溇度に变化か観測されたことを報告した。

本論文では遊離ガス中の $\mathrm{CO}_{2}$ と $\mathrm{CH}_{4}$ の炭素同位体 比, 涌水中の酸素同位体比と水素同位体比および, 溶存 イオン濃度を新たに測定するとともに，現在までの地球 化学的研究結果を総合的に解析し, 湧水およびそれに付 随する遊離ガスの起源を推定した．さらに，電気探査に より明らかにされた地下深部の良導層および, 自然地長 を使って全国の群発地票地域で次々に発見された地票波 反射面の存在を重要な情報として捕らえ、今回の測定結 果から推定した流体との関連についても言及した。

\section{§ 2. 試料採取地点およびその摡要}

\section{1 沐水およひガス武料採取地点}

遊㒧ガスと地下水試料を松代地震断層 [Nakamura and Tsuneishi (1966)] 上および，加賀井地区，田中地 区，皆神山裾野の 14 地点から採取し (Fig. 1), $\mathrm{CO}_{2}$ と $\mathrm{CH}_{4}$ の炭素同位体比, 酸素・水素同位体比, $\mathrm{CH}_{4} / \mathrm{C}_{2} \mathrm{H}_{6}$ 比および, 主要溶存イオン成分を測定した.

\section{2 採取地点の概要}

採取地点の概要を以下に示す (Fig. 1 を参照). (1) OSN-U: 掘削深度 $30 \mathrm{~m}$ の井戸からの自然湧水である. $\mathrm{CO}_{2}$ と $\mathrm{N}_{2}$ が主成分で, そのうち $\mathrm{CO}_{2}$ を 87 94\%, $\mathrm{CH}_{4}$ を $250 〜 500 \mathrm{ppm}, \mathrm{C}_{2} \mathrm{H}_{6}$ を 16〜25 ppm 含むガスが遊 離している. 水温は約 $27^{\circ} \mathrm{C}$ である. (2) OSN-L: 掘削深 度 $360 \mathrm{~m}$ の井戸からの自然湧水であり，遊離ガスが付 随している. 水温は約 $23^{\circ} \mathrm{C}$ である. (3) ICK-1: 掘削深 度 $86 \mathrm{~m}$ の井戸からの自然湧水である. $\mathrm{CO}_{2}$ と $\mathrm{N}_{2}$ が主 成分で，そのうち $\mathrm{CO}_{2}$ を 72 93\%, $\mathrm{CH}_{4}$ を 2,000 $2,600 \mathrm{ppm}, \mathrm{C}_{2} \mathrm{H}_{6}$ を $14 \sim 20 \mathrm{ppm}$ 含むガスが遊離して いる. 水温は約 $38^{\circ} \mathrm{C}$ である. (4) ICK-3: 掘削深度 122 $\mathrm{m}$ の井戸からの自然湧水である. $\mathrm{CO}_{2}$ と $\mathrm{N}_{2}$ が主成分 で, そのうち $\mathrm{CO}_{2}$ を 75〜96\%, $\mathrm{CH}_{4}$ を $30 \sim 240 \mathrm{ppm}$, $\mathrm{C}_{2} \mathrm{H}_{6}$ を 14〜21 ppm 含むガスが遊離している．水温は 約 $41^{\circ} \mathrm{C}$ である. (5) MATK: 掘削深度 $600 \mathrm{~m}$ の井戸か らの自然湧水であり， $\mathrm{CO}_{2}$ を主成分とするガスが遊解し ている. 水温は約 $43^{\circ} \mathrm{C}$ である. (6) MAT: 潜在断㢄上 に位置する掘削深度 $600 \mathrm{~m}$ の井戸からの自然洒水であ 


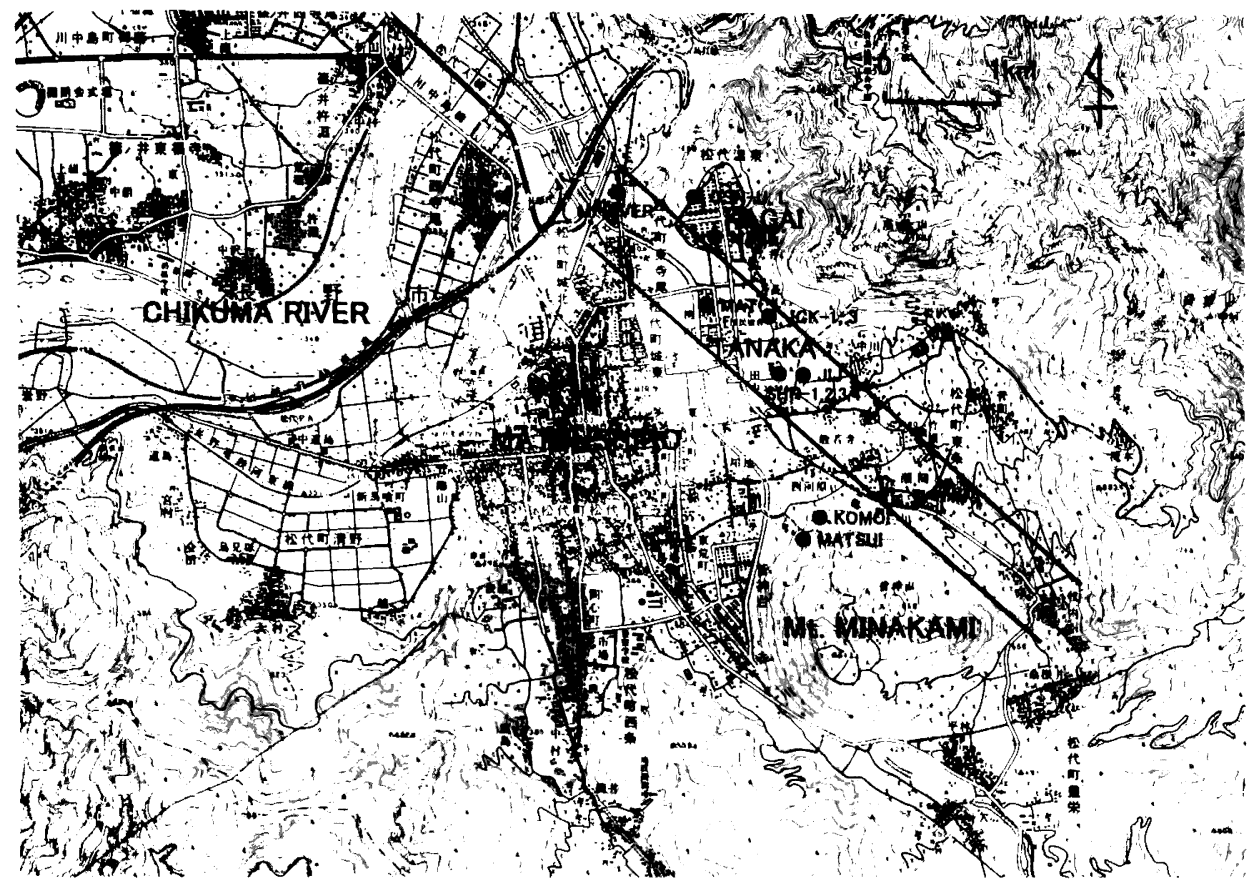

Fig. 1. Locations of measurement points $(\bullet)$.

The area between 2 lines indicates the zone of buried Matsushiro earthquake faults. The base map is a $1: 25,000$ "Matsushiro" topographic map issued by the Geographical Survey Institute.

3. $\mathrm{CO}_{2}$ と $\mathrm{N}_{2}$ が主成分で，そのうち $\mathrm{CO}_{2}$ を $87 \sim 97 \%$. $\mathrm{CH}_{4}$ を 58〜115 ppm, $\mathrm{C}_{2} \mathrm{H}_{6}$ を 10〜20 ppm 含むガス が遊離している. 水温は約 $46^{\circ} \mathrm{C}$ である. (7) SHR-1: 老 人の家 (尚和寮) 前の水田に群発地祳の際に涌出したも ので, Wakita et al. (1978)によれば、ここから採取し たヘリウムガスの同位体比がマントル起源の值を示し た. 水温は約 $28^{\circ} \mathrm{C}$ である. (8) SHR-2, SHR-3: SHR-1 から東へ $50 \mathrm{~m}$ ほど離れた尾根際の湧水であり，遊離力 スを付随する. 水温は約 $24^{\circ} \mathrm{C}$ である. (9) SHR-4: SHR1 から西へ $50 \mathrm{~m}$ ほどの涌水地点で遊離ガスを付随す る. 水温は約 $23^{\circ} \mathrm{C}$ である. (10) JIJ: SHR-1 の山を挟ん で東側の小川に流れ込む湧水である，遊離ガスは付随し ない. 水温は約 $23^{\circ} \mathrm{C}$ である. (11) MATSUI: 皆神山の 椐野にある自然湧水であり，遊離ガスは付随しない，水 温は約 $17^{\circ} \mathrm{C}$ である. (12) KOMOI: 皆神山の裾野にある 自然漂水であり，遊離ガスは付随しない. 水温は約 $17^{\circ} \mathrm{C}$ である. (13) M. RIVER: 松代町内を流れる河川であり， この河川水の分析結果を松代の地表水の値とした. 水温 は末測定である.
2.3 酸素・水素同位体比およひ，炭素同位体比の測定

酸素・水素同位体比の測定は(株)地球科学研究所に, 炭素同位体比の測定は(株)三菱マテリアルに依頼した。

酸素同位体比は水一二酸化炭素平衡法により測定した。 まず，試料水とガスを $25^{\circ} \mathrm{C}$ の恒温水槽中で $\mathrm{CO}_{2}$ と同位 体交換平衡状態にする．次に $\mathrm{CO}_{2}$ ガスのみを真空装置 内に移し，液体窒素などで水蒸気を除去する，この精製 した $\mathrm{CO}_{2}$ ガスを Nuclide Associates 社製の 6-60 型質 量分析計に導入し，酸素同位体比を測定した，測定精度 は $\pm 0.2 \%$ 程度である.

水素同位体比は金属亜鉛選元法により測定した，試料 水と粒状亜鈶を真空装置内人入れ，水化した後，反応容 器内を真空にして密封する. その反応容器を $500^{\circ} \mathrm{C} て ゙$ 約 30 分間加熱し，氷化した試料水を $\mathrm{H}_{2}$ に還元する.こ の $\mathrm{H}_{2}$ ガスをVG 社製 MM $602 \mathrm{C}$ 型質量分析計に䢙入 し, 水素同位体比を測定した，測定精度は $\pm 1 \%$ 程度で ある.

炭素同位体比は試料ガスを液体窒素で $\mathrm{CH}_{4}$ と $\mathrm{CO}_{2}$ に 分離した後， $\mathrm{CH}_{4}$ については $900^{\circ} \mathrm{C}$ で $\mathrm{CuO}$ に通し，生 成した $\mathrm{CO}_{2}$ を精彆した後，質量分析計に導入し，炭素同 
Table 1. $\delta{ }^{18} \mathrm{O}, \delta \mathrm{D}$, and the major ion concentration in water from the Matsushiro earthquake swarm area.

\begin{tabular}{|c|c|c|c|c|c|c|}
\hline Site & Sampling Date & $\begin{array}{r}\text { Depth } \\
m\end{array}$ & $\begin{array}{r}\delta^{18} 0 \\
\%_{0}\end{array}$ & $\begin{array}{l}\delta \mathrm{D} \\
\%_{0}\end{array}$ & $\begin{array}{c}\mathrm{Na}^{+} \\
\mathrm{meg} / \mathrm{I}\end{array}$ & $\begin{array}{c}\mathrm{Cl}^{-} \\
\mathrm{meg} / \mathrm{l}\end{array}$ \\
\hline \multirow[t]{11}{*}{$O S N-U$} & 1999.06 .03 & -30 & -6.4 & -64.1 & 123 & 170 \\
\hline & 1999.10 .29 & & -6.7 & -67.2 & 117 & 145 \\
\hline & 1999.11 .03 & & -6.8 & -67.2 & 122 & 148 \\
\hline & 1999.11 .10 & & -6.7 & -65.2 & 123 & 149 \\
\hline & 1999.11.17 & & -6.8 & -63.4 & 123 & 147 \\
\hline & 1999.11 .24 & & -6.8 & -63.1 & 124 & 148 \\
\hline & 2000.01 .26 & & -6.6 & -61.2 & 119 & 161 \\
\hline & 2000.03 .08 & & -6.5 & -62.5 & 124 & 173 \\
\hline & 2000.04 .24 & & -6.4 & -63.2 & 124 & 161 \\
\hline & 2000.06 .04 & & -6.5 & -61.0 & 126 & 166 \\
\hline & 2000.10 .12 & & -6.9 & -59.2 & 118 & 159 \\
\hline OSN-L & 1999.06 .03 & -360 & -4.7 & -60.6 & 154 & 222 \\
\hline \multirow[t]{5}{*}{ ICK-1 } & 1999.06 .03 & -86 & -6.4 & -62.8 & 95 & 169 \\
\hline & 1999.10.29 & & -6.4 & -63.6 & 94 & 171 \\
\hline & 1999.11 .10 & & -6.7 & -62.7 & 101 & 161 \\
\hline & 1999.11.17 & & -6.7 & -63.4 & 98 & 157 \\
\hline & 1999.11 .24 & & -6.6 & -62.7 & 98 & 158 \\
\hline \multirow[t]{2}{*}{ ICK-3 } & 1999.06 .03 & -122 & -6.2 & -63.5 & 96 & 180 \\
\hline & 1999.10.29 & & -6.1 & -62.3 & 94 & 172 \\
\hline MATK & 1999.06 .03 & -600 & -3.6 & -52.1 & 150 & 240 \\
\hline \multirow[t]{10}{*}{ MAT } & 1999.06 .03 & -600 & -3.6 & -52.7 & 148 & 240 \\
\hline & 1999.10 .29 & & -4.1 & -60.7 & 154 & 235 \\
\hline & 1999.11 .03 & & -4.3 & -58.1 & 147 & 221 \\
\hline & 1999.11 .10 & & -4.2 & -58.0 & 149 & 219 \\
\hline & 1999.11 .17 & & -4.4 & -57.6 & 148 & 215 \\
\hline & 1999.11 .24 & & -4.3 & -54.0 & 146 & 215 \\
\hline & 2000.01 .26 & & -4.4 & -53.2 & 138 & 226 \\
\hline & 2000.03 .08 & & -4.2 & -53.2 & 139 & 226 \\
\hline & 2000.06 .04 & & -4.4 & -53.3 & 140 & 216 \\
\hline & 2000.10 .12 & & -3.9 & -51.3 & 145 & 235 \\
\hline \multirow[t]{6}{*}{ SHR-1 } & 1999.06 .03 & unknown & -9.1 & -72.1 & 26 & 73 \\
\hline & 1999.10 .29 & & -9.2 & -71.9 & 28 & 71 \\
\hline & 1999.11 .03 & & -9.0 & -71.0 & 29 & 71 \\
\hline & 1999.11 .10 & & -9.2 & -73.5 & 30 & 73 \\
\hline & 1999.11.17 & & -9.2 & -71.0 & 27 & 72 \\
\hline & 1999.11 .24 & & -9.2 & -71.4 & 29 & 71 \\
\hline SHR-2 & 1999.06 .03 & unknown & -10.1 & -75.5 & 18 & 42 \\
\hline SHR-3 & 1999.06 .03 & unknown & -10.0 & -75.1 & 20 & 49 \\
\hline SHR-4 & 1999.06 .03 & unknown & -9.0 & -73.2 & 35 & 85 \\
\hline JIJ & 1999.06 .03 & unknown & -10.9 & -76.9 & 5 & 29 \\
\hline MATSUI & 1999.06 .03 & unknown & -11.5 & -77.8 & 2 & 3 \\
\hline KOMOI & 1999.06 .03 & unknown & -11.3 & -80.5 & 3 & 2 \\
\hline M. RIVER & 1999.06 .03 & & -10.3 & -71.5 & 1 & 1 \\
\hline
\end{tabular}

位体比を測定した. $\mathrm{CO}_{2}$ についてはさらに $\mathrm{SO}_{2}, \mathrm{H}_{2} \mathrm{O}$ な どを除去した後, $\mathrm{CH}_{4}$ と同様な方法で $\mathrm{CO}_{2}$ を精製し，炭 素同位体比を測定した，使用した質量分析計は Micromass 社製質量分析計 OPTIMA である. 测定精度は $\mathrm{CH}_{4}, \mathrm{CO}_{2}$ 共に $\pm 0.2 \%$ 程度である.

\section{§3. 結果およひ考察}

3.1 汤水の起源

湧水の起源を議論しようとする時, 水を構成する酸菜
と水素の安定同位体比 $\left(\delta^{18} \mathrm{O}, \delta \mathrm{D}\right)$ が利用される. 良く 知られているように, 地表水 (天水) は, $\delta^{18} \mathrm{O}$ と $\delta \mathrm{D}$ と の間に一定の関係があり $\left(\delta \mathrm{D}=8 \delta^{18} \mathrm{O}+10\right)$, 湧出水が 天水起源かどうかの判定にこの関係が利用される [Craig (1961b)]. また，涌水に溶存する Cl は，岩石鉱 物中に含まれないために, 水と岩石との化学反応によっ ては增減がないので, $\mathrm{Cl}^{-}$㵏度も, 涌水の起源が同一か どうかの判定に利用される [例えば、松葉谷 (1991)]. そ こで, 松代群発地票地域から採取した河川水と種々の涌 


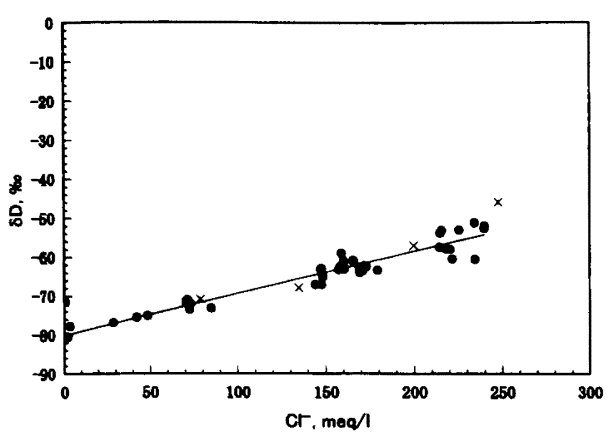

Fig. 2. Relationship between $\delta \mathrm{D}$ and $\mathrm{Cl}$ content.

- Our data, and $\times$ data after Matsubaya [1976]. The straight line is the best fit for data.

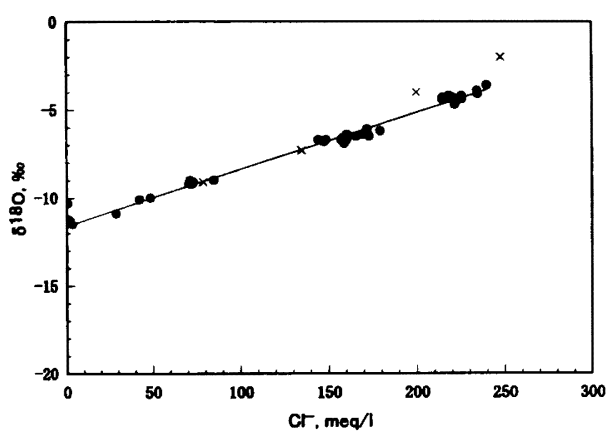

Fig. 3. Relationship between $\delta^{18} \mathrm{O}$ and $\mathrm{Cl}$ content.

- Our data, and $\times$ data after Matsubaya [1976]. The straight line is the best fit line for data.

水の同位体比 $\left(\delta^{18} \mathrm{O}, \delta \mathrm{D}\right)$ およひ，主要溶存イオン成分 である $\mathrm{Na}^{+}$濃度と $\mathrm{Cl}^{-}$濃度を分析した。 その結果を Table 1 に示す.

一般に水菜は造岩鉱物の中に少なく，酸素は非常に多 いので, 深層水は造岩鉱物と反応すれば同位体交換が起 き, $\mathrm{H}_{2} \mathrm{O}$ の酸素は $\delta^{18} \mathrm{O}$ の増加する方向に変化するとい われている.そこで, $\delta \mathrm{D} と \mathrm{Cl}^{-}$濃度の関係, および $\delta^{18} \mathrm{O}$ と $\mathrm{Cl}^{-}$灌度の関係を調へてみる. Fig. 2 と Fig. 3

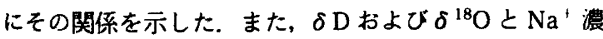
度との関係を Fig. 4, Fig. 5 に示した. 図中のシンボル の大きさは $\delta^{18} \mathrm{O}, \delta \mathrm{D}$ の測定精度を示す.

$\delta \mathrm{D}$ と $\mathrm{Cl}^{-}$蕽度の関係および, $\delta^{18} \mathrm{O}$ と $\mathrm{Cl}^{-}$浱度の関 係共に良く直線の上に乗っていることが判る.これは次 のような解釈が可能である，まず，塩素は造岩鉱物中に

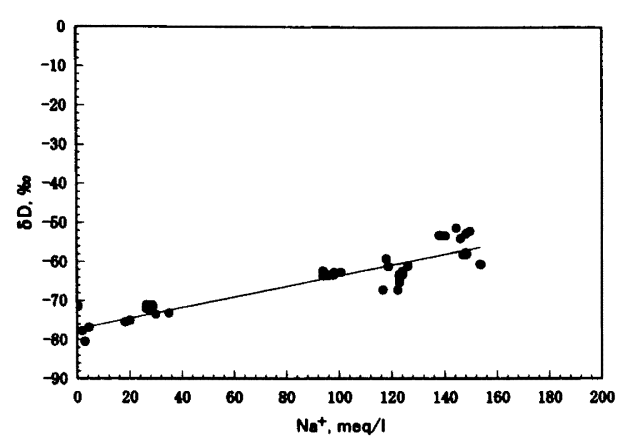

Fig. 4. Relationship between $\delta \mathrm{D}$ and $\mathrm{Na}^{+}$content.

The straight line is the best fit for data.

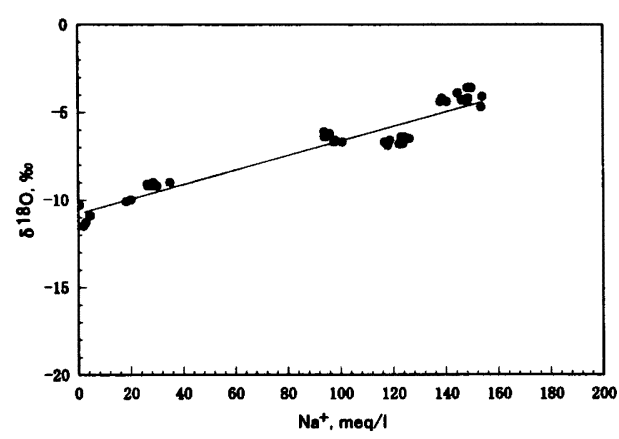

Fig. 5. Relationship between $\delta^{18} \mathrm{O}$ and $\mathrm{Na}^{+}$ content.

The straight line is the best fit for data.

は少ないので， $\mathrm{Cl}$ 濃度は岩石との反応の影響は殆ど受 けず, その変化は高濃度の深首水上低濃度の河川水に代 表される浅層水との混合比率のみによっていると考えて 良い.この $\mathrm{Cl}^{-}$濃度変化と直線関係にあるということ は，その直線関係にある化学成分も岩石との反応による 濃度変化は少なく、混合比率の睡いによって濃度が決め られている化学成分であるということになる。これは， 各湧水を供給している各帯水層中では，水と岩石の反応 が遅く重酸素の蕽縮が目に見えるはどは起きていないこ との証拠でもある.

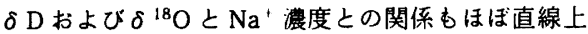
にデータが乗っている.これも混合によるのだとすれ ば，深層水は 1 種類であるということである．採取した 湧水の $\delta^{18} \mathrm{O}$ と $\delta \mathrm{D}$ との関係を Fig. 6 に示す. 図中のシ ンボルの大きさは $\delta^{18} \mathrm{O}, \delta \mathrm{D}$ の測定精度を示す。ほぼ直 線上に全てのデータが乗っているのが見える.ささらに， 天水を示す直線とは明らかに異なるが，天水直線とデー 


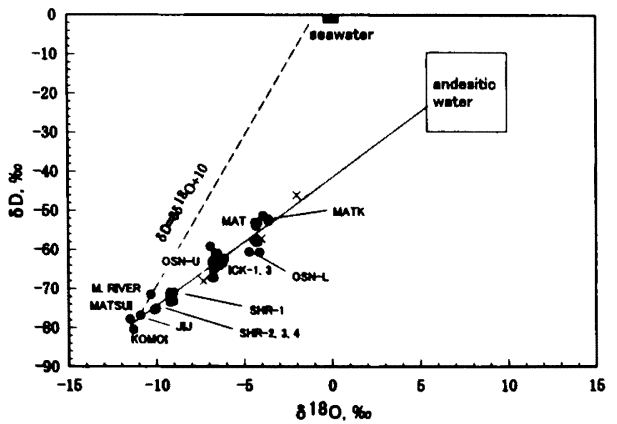

Fig. 6. Relationship between $\delta^{18} \mathrm{O}$ and $\delta \mathrm{D}$. - Our data, and $\times$ data after Matsubaya [1976]. The straight line is the best fit for data. The dashed line $\delta \mathrm{D}=8 \delta^{18} \mathrm{O}+10$ is the best fit for meteoric water. The square of andesitic area indicates the isotope ratio ranges from Giggenbach [1992].

夕の近似直線との交点に松代地域を流れる河川水あるい は浅層水の $\delta^{18} \mathrm{O}, \delta \mathrm{D}$ 值があるのが判る.つまり,この データから, 松代の種々の涌水は松代の河川水之地下深 部にあると見られる 1 種類の深層水との 2 液混合で成 立していることがわかる. その 1 種類の深層水の同位体 組成は, Fig. 6 のグラフの近似直線の延長上のどこかに あるはずであるが, どこであるかはこのデータだけから は特定できない，なお，松葉谷・他(1980)によるデー夕 も Fig. 6 にはプロットしてある. 松葉谷は，傾きの異な る 2 本の直線で近似できるとしたが，Fig. 6 に見るよう に，本研究による多数の測定結果からは，1本の直線で 十分近似できることがわかる。

ところで, Giggenbach (1992) は島弧のマグマが令 却・固結する時放出される水の同位体組成を、数多くの 火山ガス，地熱水の湘定データから経験的に推定した。 それを “andesitic water” (安山岩マグマ水) と名付け， $\delta{ }^{18} \mathrm{O}=+5 \sim+10 \%, \delta \mathrm{D}=-30 \sim-10 \%$ の範囲にある とした (Fig. 6). 本研究により得られた混合直線が安山 岩マグマ水の範囲を通ることがわかる。

松代の深層水は松代群発地票を起こした水である [例 えば, 大竹 (1976)]. 地票は, 深度 2〜15 km の範囲で 活発に発生した. 少なくとも同程度の深度, あるいはそ れより深いところからの高圧の水が進入してきたものと 考えられるので，その水は下部地款あるいはマントルか ら由来したものであろう．そのような深さで水が放出さ れる現象は火成作用あるいは変成作用に関わった現象で あろう. 変成作用を否定する材料はなにもないが，少な くとも Giggenbach (1992) の経験則に良く合うという
意味で，深居水の最有力候補として安山岩マグマ水をこ こで提案する。この安山岩マグマ水が群発地蜄を引き起 こし，松代の現在の湧出水は，松代の天水や浅首水之安 山岩マグマ水とが種々の割合で混合して, 涌出している というモデルである.

松葉谷・他 (1980) は松代の湧水を化石海水と天水と の混合とした，しかし，Fig. 6 に示すように近似直線は， 海水の値を通らない.これについては松葉谷・他 (1980) は化石海水が周囲の岩石上の酸菜同位体交換により重酸 秦を洊縮したことによるものとした，深度 $2 \mathrm{~km}$ より深 部の水が上昇してきて地票を起こしたとすると、深首地 下水が化石海水であるというのは考えにくい.

3.2 河出深度と汤水の化学組成, 同位体比

群発地縟発生 4 年後に高橋 (1970)により松代在内に $1,800 \mathrm{~m}$ の深さの調査用ボーリング孔が掘削され，唡水 の調査が行われた，涌水は深度およそ $1,320 \mathrm{~m}$ まで鉄 管が挿入された後も続いた。この湧水の湧出深度を正確 に決めることはできないが，およそ $1,600 \mathrm{~m}$ に破硡帯 が見られることから考えると，おそらくこの深度からの 涌水であろうと思われる。このボーリングれから採取さ れた湧水の $\mathrm{Na}^{\prime}$ 灌度は $283 \sim 311 \mathrm{meq} / l, \mathrm{Cl}$ 浱度は $326 \sim 338 \mathrm{meq} / l$ である [地質調查所 (1979a)]. この值 が採取された深部流体の分析值の中で最も高浱度つま り，最も浅層水の混合率が低い試料である.

われわれは群発地票発生以前から存在していた地下水 は，おそらく地票を引き起こした多量の深部流体と置き 換わったであろうとし、このボーリングれから自噴した 湧水の成分を深部流体に極めて近いものと考えた．湧水 深度と本研究で得られたデータも含めて $\mathrm{Na}^{+}$沄度, $\mathrm{Cl}^{-}$

湍度， $\delta^{18} \mathrm{O}$ および $\delta \mathrm{D}$ との関係をそれぞれ Fig. 7, Fig. 8 に示す. 深度に対してほぼ直線的に変化しているのか わかる. 図中の直線は湧水の値から得られた回帰直線て ある. 図中のシンボルの大きさはそれぞれの測定精度を 示す.

Fig. 8からわかるように安山岩マグマ水に相当する $\delta{ }^{18} \mathrm{O}, \delta \mathrm{D}$ の値に到達する深度は約 $2,000 \mathrm{~m}$ となって いる. $2.000 \mathrm{~m}$ より深部では希积されていない安山岩マ グマ水で裂は満たされていると推定される.つまり, この地域の天水の循環深度は $2,000 \mathrm{~m}$ くらいまでだと いうことである. また, この Fig. 7 からその安山岩マグ マ水の $\mathrm{Na}^{+}$㧼度, $\mathrm{Cl}^{-}$灌度はそれぞれ $350 \mathrm{meq} / \mathrm{l}, 380$ $\mathrm{meq} / l$ 以上であると推定される. 奥澤・塚原 (2001) は $1,600 \mathrm{~m}$ 深の地下水を深部起源水そのものと考えたか， 以上の結果から， $1,600 \mathrm{~m}$ の地下水さえも薄められてい たと結論する方が理にかなっている. 

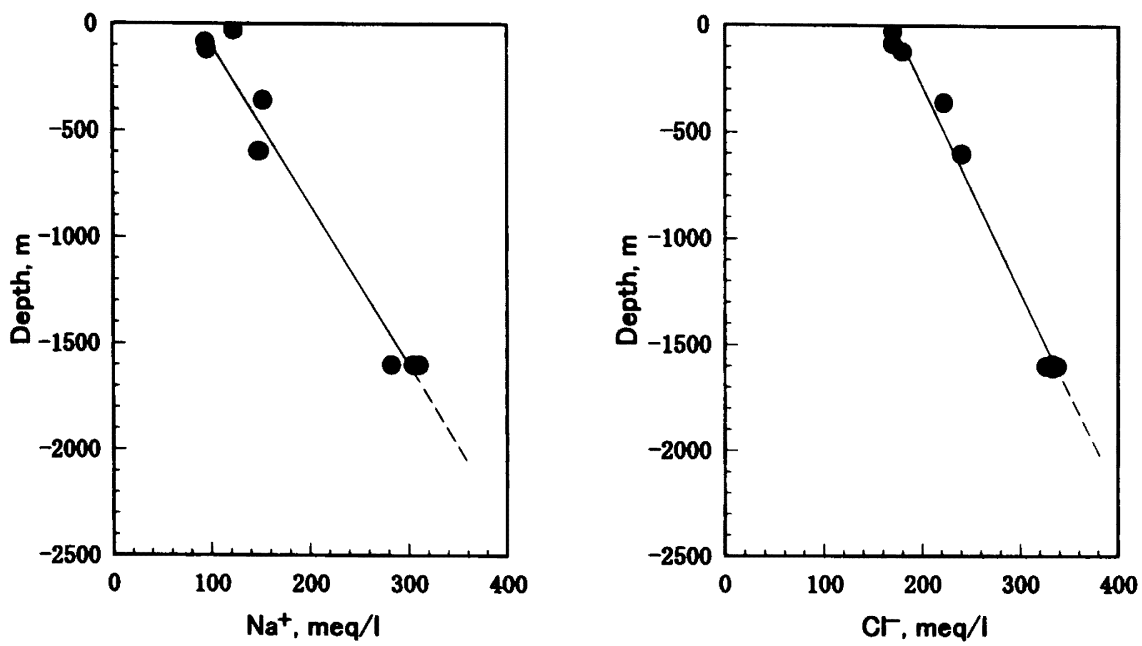

Fig. 7. Plots of $\mathrm{Cl}$ and $\mathrm{Na}^{\prime}$ and against depth.

Solid and dashed line is the regression line for measured data.

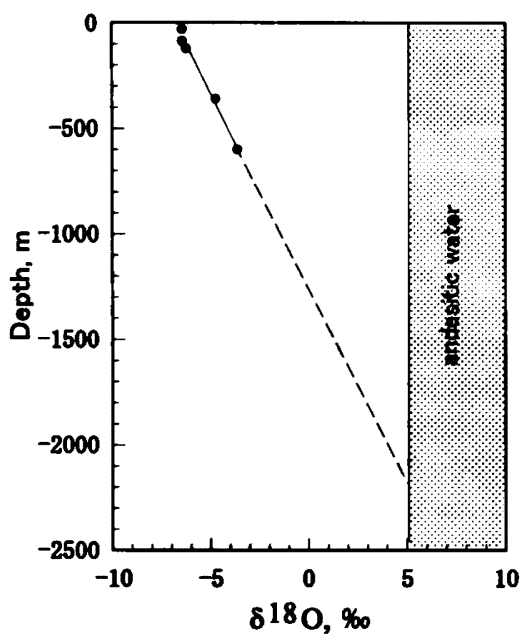

a

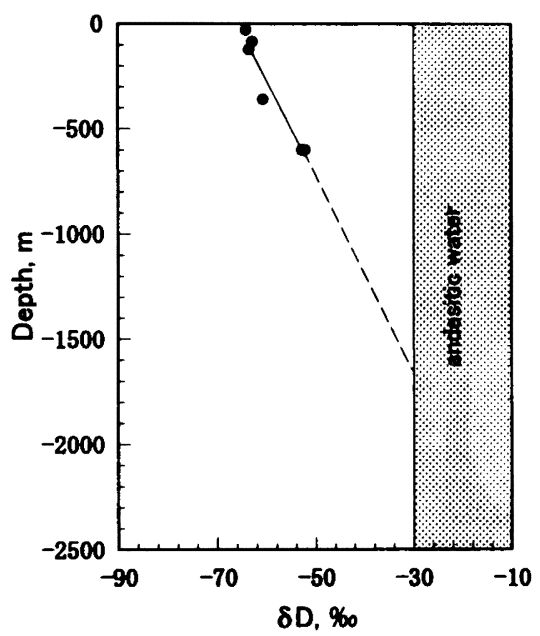

b

Fig. 8. Plots of $\delta^{18} \mathrm{O}$ and $\delta \mathrm{D}$ against depth.

Solid and dashed is the regression line for measured data. Shading in a and $\mathbf{b}$ indicate andesitic magmatic water.

$3.3 \mathrm{CO}_{2}$ と $\mathrm{CH}_{4}$ の起源

松代地域の遊離ガス組成をTable 2 に示した. 主成分 は $\mathrm{CO}_{2}$ で， $\mathrm{N}_{2}$ を加えるとほぼ $100 \%$ になる。

Berner and Faber (1993) は, $\mathrm{CH}_{4}$ の炭素同位体比之 $\mathrm{CH}_{4} / \mathrm{C}_{2} \mathrm{H}_{6}$ 比から, $\mathrm{CH}_{4}$ をハクテリア起源, 有機物の熱 分解起源に経験的に分類できることを示した. そこで，
$\mathrm{CH}_{4} / \mathrm{C}_{2} \mathrm{H}_{6}$ 比と $\delta{ }^{13} \mathrm{C}\left(\mathrm{CH}_{4}\right)$ との関係を Fig. 9 に示した. 図中のシンボルの大きさは炭素同位体比の測定精度を示 す. 図中の枠は Berner and Faber (1993) と佐藤・他 (1999)によるものである. $\mathrm{CH}_{4}$ の炭素同位体比が測定さ れた 3 個のデー夕は $\mathrm{CH}_{4}$ が熱分解起源であることを示 している.つまり, $\mathrm{CH}_{4}$ は堆積物中の有機物が地下深部 
Table 2. $\delta{ }^{13} \mathrm{C}\left(\mathrm{CH}_{4}\right), \delta{ }^{13} \mathrm{C}\left(\mathrm{CO}_{2}\right)$, and the major gas concentration of free gas in water from the Matsushiro earthquake swarm area.

\begin{tabular}{|c|c|c|c|c|c|c|c|c|}
\hline Site & Sampling Date & $\begin{array}{r}\text { Depth } \\
m\end{array}$ & $\begin{array}{r}\mathrm{CO}_{2} \\
\times \\
\end{array}$ & $\begin{array}{c}\mathrm{CH}_{4} \\
\mathrm{ppm}\end{array}$ & $\begin{array}{l}\mathrm{C}_{2} \mathrm{H}_{\mathrm{B}} \\
\mathrm{ppm}\end{array}$ & $\mathrm{CH}_{4} / \mathrm{C}_{2} \mathrm{H}_{6}$ & $\begin{array}{r}8{ }^{13} \mathrm{C}\left(\mathrm{CH}_{4}\right) \\
\%_{0}\end{array}$ & $\begin{array}{r}\delta^{13} \mathrm{C}\left(\mathrm{CO}_{2}\right) \\
\%_{0}\end{array}$ \\
\hline$\overline{O S N}-\mathrm{U}$ & $\begin{array}{l}1999.01 .29 \\
1999.02 .12 \\
1999.06 .03 \\
2000.10 .12\end{array}$ & -30 & $\begin{array}{l}93 \\
87 \\
94 \\
90\end{array}$ & $\begin{array}{l}493 \\
285 \\
255 \\
286\end{array}$ & $\begin{array}{l}20 \\
18 \\
25 \\
16\end{array}$ & $\begin{array}{l}24 \\
16 \\
10 \\
17\end{array}$ & -30.4 & -4.0 \\
\hline MAT & $\begin{array}{l}1999.01 .29 \\
1999.02 .12 \\
1999.06 .03\end{array}$ & -600 & $\begin{array}{l}87 \\
90 \\
97\end{array}$ & $\begin{array}{r}115 \\
58 \\
73\end{array}$ & $\begin{array}{l}20 \\
10 \\
10\end{array}$ & $\begin{array}{l}6 \\
6 \\
7\end{array}$ & & -4.8 \\
\hline ICK-1 & $\begin{array}{l}1999.01 .29 \\
1999.02 .12 \\
1999.06 .03\end{array}$ & -86 & $\begin{array}{l}72 \\
93 \\
78\end{array}$ & $\begin{array}{l}2619 \\
2140 \\
1916\end{array}$ & $\begin{array}{l}20 \\
15 \\
14\end{array}$ & $\begin{array}{l}128 \\
147 \\
141\end{array}$ & & -5.3 \\
\hline ICK-3 & $\begin{array}{l}1998.10 .15 \\
1999.01 .29 \\
1999.02 .12 \\
1999.06 .03 \\
2000.10 .12\end{array}$ & -122 & $\begin{array}{l}75 \\
94 \\
75 \\
96 \\
93\end{array}$ & $\begin{array}{r}163 \\
161 \\
237 \\
30 \\
157\end{array}$ & $\begin{array}{l}19 \\
21 \\
16 \\
14 \\
17\end{array}$ & $\begin{array}{r}8 \\
8 \\
15 \\
2 \\
10\end{array}$ & -26.3 & $\begin{array}{l}-5.4 \\
-5.2\end{array}$ \\
\hline SHR-1 & $\begin{array}{l}1998.10 .15 \\
1999.01 .29 \\
1999.02 .12 \\
1999.06 .03 \\
2000.10 .12 \\
\end{array}$ & unknown & $\begin{array}{l}90 \\
90 \\
82 \\
92 \\
91 \\
\end{array}$ & $\begin{array}{r}194 \\
155 \\
150 \\
98 \\
113 \\
\end{array}$ & $\begin{array}{l}20 \\
22 \\
16 \\
11 \\
12 \\
\end{array}$ & $\begin{array}{r}10 \\
7 \\
9 \\
9 \\
9 \\
\end{array}$ & -18.8 & $\begin{array}{l}-7.1 \\
-7.0 \\
-5.1\end{array}$ \\
\hline
\end{tabular}

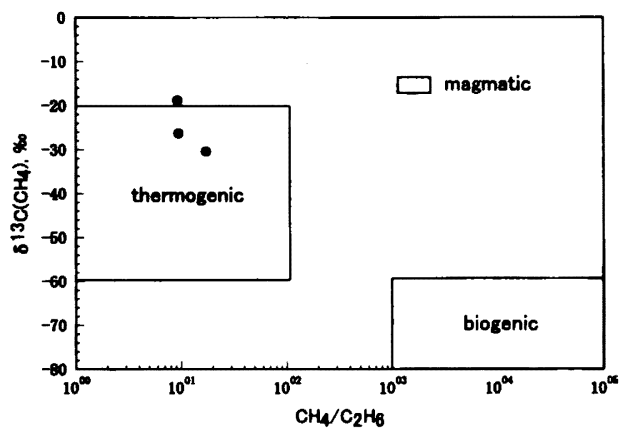

Fig. 9. Plots of $\delta^{13} \mathrm{C}$ of $\mathrm{CH}_{4}$ against the ratio of $\mathrm{CH}_{4} / \mathrm{C}_{2} \mathrm{H}_{6}$.

Specimens are from free gas in upwelling water at OSN-U, ICK-3, and SHR-1. indicates values obtained from the pres. ent study.

で熱分解された結果, 生成した $\mathrm{CH}_{4}$ であることを示し ている. 炭素同位体比の測定されていない試料も。 Table 2 に示されるように, $\mathrm{CH}_{4} / \mathrm{C}_{2} \mathrm{H}_{6}$ 比が 2 150で あるので熱分解の $\mathrm{CH}_{4}$ であることを支持している.

起源となる有機物と，それを分解する熱は松代直下に あるだろうか.この地域の, 唯一の深首調查ボーリング は，高橋 (1970)による松代荘構内で実施されたもので ある.斉藤(1970)は、このボーリングデータを、深度 $97 \mathrm{~m}$ までが第四系で, その下から深度 $1,680 \mathrm{~m}$ までは 中期中新世堆積岩および火山岩類，さらにその下は，貫 入岩である石英閃緑岩と解釈している.なお, 深度 $1,800 \mathrm{~m}$ のボーリング孔底の温度は, ボーリング直後の
測定で $98^{\circ} \mathrm{C}$ (高橋, 1970) であった. この温度は, 深度 $1,680 \mathrm{~m}$ 以浅に見られた堆積岩中の有機物の熱分解に は十分の温度 $\left(75^{\circ} \mathrm{C}\right)$ である. 熱分解 $\mathrm{CH}_{4}$ はここで生成 された可能性は十分ある.

$\mathrm{CO}_{2}$ の炭素同位体比の值は $-7.1 \% 0-3.1 \%$ である. この値は有機物起源ではなく、マンンル (マグマ)起源 の $\mathrm{CO}_{2}$ あるいは大気 $\mathrm{CO}_{2}$ の炭素同位体比の値に相当す ろが，遊離ガス中に $\mathrm{CO}_{2}$ が $72 \%$ ～96\% という高濃度 で含まれることから大気起源ではなく、、ントル（マグ マ）起源と考えられる. 採取地点近傍に位置する皆神山 が第四紀の火山活動で生じた溶岩円頂丘であり [沢村 ・ 他 (1967)], 金子・他 (1991) による皆神山の溶岩の年代 測定では，噴出時期は約 30 万年前と新しいので，この 火成活動と関係があることは十分考えられる.さらに Wakita et al. (1978) は松代地域から放出されるへリウ ムの同位体比がマントルの値に近いことから, ヘリウム はマントルに由来するとしている.

以上のように，湧出ガスは起源の異なる，少なくとも 2 種のガスから成っていることが判った，最も主要なが

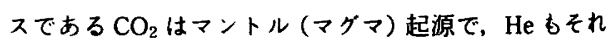
に付随していると考えられ, 地款深部少なくとも堆積岩 首より下から湧出してきたものである. 一方, $\mathrm{CH}_{4}$ は有 機物起源なので, 深部 $\left(75^{\circ} \mathrm{C}\right.$ 以上高温の) 堆積岩から涌 出してきたものである. なお, $\mathrm{CO}_{2}$ に次いで量の多い $\mathrm{N}_{2}$ については，その起源に関して議論できるデータは今の ところ得られていない.

\section{4 深部起源水の河出椱模}

地縟と関わりのある前述の深部起源水の具体的な湧出 機樓はどのようなものであろうか，森本・他 (1966), 金 


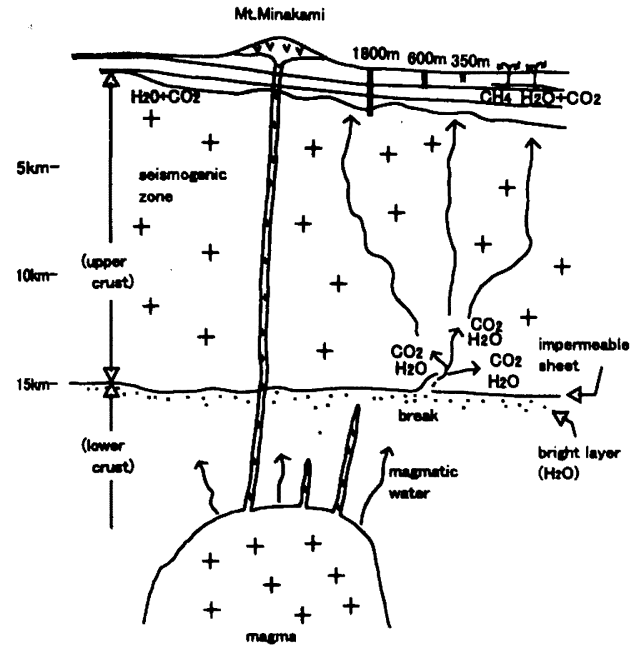

Fig. 10. Origin of groundwater and earthquake occurrence.

Water and $\mathrm{CO}_{2}$ gas are released from magma when andesitic magma solidifies. Water and $\mathrm{CO}_{2}$ gas accumulate below an impermeable sheet formed with precipitates from magmatic water. The magmatic water layer corresponds to the observed reflection bright layer and electric conductive layer under this area. When the impermeable sheet broke and highpressure water with $\mathrm{CO}_{2}$ rose into the upper crust, the crust was weakened, causing the Matsushiro earthquake.

子・他 (1991)によれば皆神山溶岩の K-Ar 絶対年代は それぞれ 35 万年, 29 万年である. 当時, 安山岩マグマ から脱水したマグマ水が下部地殼に存在していたはずで おる，現在，松代群発地莀地域の地下 $15 \mathrm{~km}$ には面状 に広がる地票波反射面の存在か知られている[西脇・他 (1989)]. 大柣・他 (1998) は，日本各地に，同深度付近 に発見された反射面をブライトレイヤーと称し，帯水冨 であるとした，そして，この帯水層から流体が流出し， 内陸地票が発生すると主張した，松代群発地票の原因で ある湧水の源が，安山岩マグマ水であるとする本研究の 結論は，大柣らのモデルに重要な影䨢を与えるものであ 3.

マグマ水が下部地款に眝留されるにはマグマ水の上側 に不透水首の存在が必要である. 高浱度の $\mathrm{Na}^{+}$と $\mathrm{Cl}^{-}$ および $\mathrm{CO}_{2}$ を含む溶液か，下部地款を上昇する過程で $\mathrm{CO}_{2}$ の脱ガスが起き，鉱物の溶解度が減少し， た殿物に よる不透水層が形成される可能性は十分にある，その不
透水首の下部にマグマ水の帯水層が形成される [Utada (1987), 世井(1994)]. しかし，この不透水首が何らかの 理由で破れたとき，多量の高圧水が地殻を上昇する，そ の過程で岩石強度を弱め群発地票を引き起こしたのであ ろう，そのとき，上昇水の圧力を高圧のまま保つのに $\mathrm{CO}_{2}$ の発泡が大きな役割を果たしたのではないか，流体 の占める体積は上昇により增えるので流体目体の圧力は 降下するが，発泡によりそれが補われ，その圧力降下は 少なかったであろうと推定される.

以上のことを、図にしたのが Fig. 10 である.

\section{§4. ま とめ}

（1）松代地域各地の涌水中の $\delta{ }^{18} \mathrm{O}$ 値, $\delta \mathrm{D}$ 値と主要 溶存イオン成分である $\mathrm{Na}^{+}$浱度, $\mathrm{Cl}^{-}$灌度とは, 良い直 線関係にあるので，松代地域全域の涌水は 2 液混合モデ ルで説明できる.

(2) $\delta \mathrm{D}$ と $\delta^{18} \mathrm{O}$ との関係を示す回帰直線は，2 液混 合成分のうち一方の成分は地表水であることを示してい る. もう一方は安山岩マグマ水の同位体比推定領域を通 る.

（3）一方、湧水に含まれる遊離ガスの主成分である $\mathrm{CO}_{2}$ ガスはマグマ起源, $\mathrm{CH}_{4}$ は熱分解起源であること が，炭素同位体比などからわかった。

（4）松代地域の湧水に付随する $\mathrm{He}$ ガスがマントル起 源であることはすでに知られているが，それに加えて上 記 (2) と (3) の結果, さらに，近くに第四紀火山があるこ とからして，2 液のうちの一方は安山岩マグマ水だと推 定した.

（5）地下に電気良導体，地震波反射面があることも考 虑し, 深度 $15 \mathrm{~km}$ 付近に滞留していた安山岩マグマ水 が、上面を遮蔽していた不透水層が破れたために上昇し て，岩盤を弱化し，松代群発地震が発生したとするモデ ルを提案した。

\section{䍶 辞}

本研究を進めるに際し、群発地票に関する文献および 情報をご教示いただいた元防災科学技術研究所 鈴木宏 芳氏およひ，試料採取のお願いを快く受け入れてくださ いました一陽館, 尚和寮, 松代荘の関係者の皆様に深く 感謝いたします，査読者である笹井洋一氏，風早康平氏 からの貫重な助言は，本論文の内容を改善するのに大变 役立ちました。ここに深く感謝いたします。

$$
\text { 文献 }
$$

Berner, U. and E. Faber, 1993, Proc. ODP, Sci. Results, 131, 185-195. 
地質調査所，1979a，松代温泉湧水の分析結果，防災科 学技術研究資料，41，37.

Craig, H., $1961 \mathrm{~b}$, Isotopic variations in meteoric waters, Science, 133, 1702-1703.

Giggenbach, W. F., 1992, Isotopic shifts in waters from geothermal and volcanic systems along convergent plate boundaries and their origin, Earth, Plan. Sci. Lett., 113, 495-510.

Healy, J. H., W. W. Rubey, D. T. Griggs and C. B. Raleigh, 1968, The Denver earthquakes, Science, 161, 1301-1310.

細野義純，1968，松代群発地祳に際し観察された地下水 位の異常と水質の変化について, 地質学雑誌， 74 569-581.

飯島 弘，1969，松代周辺の表層地質と地盤災害，防災 科学技術総合研究報告, 18, 103-116.

金子隆之・清水 智・板谷徹丸，1991，松代周辺に分布 する鲜新〜更新世火山岩類の $\mathrm{K}-\mathrm{Ar}$ 年代, 火山, 36 . 193-195.

Kisslinger, C., 1975, Processes during the Matsushiro, Japan, earthquake swarm as revealed by leveling, gravity, and spring-flow observations, Geology, 3, $57-62$.

松葉谷治・酒井均・日下部実・佐々木昭, 1980 , 長野 県の温泉についての同位体化学調査報告, 岡山大学温 泉研究所報告, 50, 17-24

松葉谷治, 1991, 熱水の地球化学, 第 7 章, 裳華房,

森本良平・村井 勇・松田時彦・中村一明・恒石幸正・ 吉田鎮男, 1966, 松代群発地震地域とその周辺地方の 地質, 地票研究所貫報, 44, 323-445.

Nakamura, K. and Y. Tsuneishi, 1966, Ground cracks at Matsushiro probably of underlying strike-slip fault origin, I-Preliminary report, Bull. Earthq. Res. Inst., 44, 1371-1384.

中村一明，1971，松代地震から学んだこと一手に入れた 地票制御へのデータ一, 科学朝日, 10, 127-133.

西脇 誠・森田裕一・流 精樹- 柿下 毅 - 長田芳一・ 永井直昭, 1989, 松代アレイで観測された SxS 波と反 射面の検出, 地震学会講演予稿集, No. 1 .

野口喜三雄・上野精一・西井戸敏夫, 1969 , 松代群発地 票にともなう温泉水の变化に関する地球化学的研究， 温泉科学, 20,67-93.

Nur, A., 1974, Matsushiro, Japan, earthquake swarm: Confirmation of the dilatancy-fluid diffusion model, Geology, 2, 217-221.

大竹政和，1976，松代地票から 10 年, 科学, 46, 306313.

大柣害四郎・梅田康弘・星野健一・土屋範芳，1998，フ
ライト計画一Bright layer の性状・成因・物理化学過 程の探求一, 地祳学会予稿集・秋季, A47.

奥澤 保・塚原弘昭，2001，松代群発地票地域に溥出す る深属地下水，地票 2,53，241-253.

奥澤 保・塚原弘昭, 2002, 松代群発地票地域に湧出す る地下水の直下地票にともなう化学成分変化, 温泉科 学, 51, 147-163.

斉藤 豊, 1970, 長野盆地形成史の再検討に関する諸問 題、第四紀，15, 4-8.

笹井洋一，1994，松代群発地縟の生成機構一自然発生的 大規模水圧破砕, Conductivity Anomaly 研究会論文 集, $181-195$

佐藤雅規・森 俊哉・野津畫治・脇田 宏, 1999, 䉘島 火山地帯から放出される喷気，温泉ガのの炭菜およひ ヘリゥム同位体比、火山、6,279-283.

沢村孝之助・垣見俊弘・曽我部正敏・小林 勇・長谷紘 和, 1967, 松代浱源域の地質之地質構造, 防災科学技 術総合研究速報, 5, 3-11.

清水直哉・塚原弘昭・古管友道・吉田則夫, 1998 , 長野 市松代地域における炭酸ガスの湧出量と地殻变動, 地 票 2, 51, 41-50.

Stuart, W. D. and M. J. S. Johnston, 1975, Intrusive origin of the Matsushiro earthquake swarm, Geology, 3, 63-67.

高橋 博, 1970 , 松代の深層ボーリングその後と，水の 圧入実験, 防災科学技術, 13, 10-13.

塚原弘昭・奥澤 保・新井 崇, 1998, 断層流体相の解 明, 月刊地球, $21,55-58$.

恒石幸正・高橋春男，1975，松代群発地縟発生機構につ いての考察, 地質学会予稿集, p. 72 .

Tsuneishi, Y. and K. Nakamura, 1970, Faulting Associated with the Matsushiro Swarm Earthquakes, Bull. Earthq. Res. Inst., 48, 29-51.

Tsunogai, U. and H. Wakita, 1995, Precursory chemical changes in ground water: Kobe earthquake, Japan, Science, 269, 61-63.

鶴見 塞, 1979, 松代浭水の化学的特徵。地球化学, 13, 18-23.

Utada, H., 1987, A direct inversion method for 2 . dimentional modeling in the geomagnetic induction problem, $\mathrm{Ph}$. D. Thesis, Univ. Tokyo, $409 \mathrm{pp}$.

Wakita, H., N. Fujii, S. Matsuo, K. Notsu, N. Takaoka, 1978, "Helium Spots": caused by a diapiric magma from the upper mantle, Science, 200, 430-432.

Yoshioka, R., S. Okuda and Y. Kitano, 1970, Calciumchloride type water discharged from the Matsushiro area in connection with swarm earthquakes, Geochem. J., 4, 61-74. 